\title{
The Implementation of Sustainable Energy Initiatives in Campus Buildings
}

\author{
Mohamad Sufian Hasim, Wan Farissa Haslin Wan Azam, \\ Ahmad Ezanee Hashim, Nor Rima Muhamad Ariff
}

\author{
Faculty of Architecture, Planning and Surveying, \\ Universiti Teknologi MARA, Malaysia \\ moham315@uitm.edu.my; sasa_wanazam@yahoo.com; ezanee54@gmail.com; norri550@uitm.edu.my
}

\begin{abstract}
Sustainable energy initiatives are one of the substantial measures toward achieving environmental sustainability goals and should be adopted by facilities management practices in university. This paper examined the sustainable energy initiatives implemented at three (3) participated universities with the objectives to identify the most current effective initiatives undertaken and to propose future improvement strategies. The perception of six (6) key persons was observed via a semi-structured interview. The most implemented strategies were establishing energy awareness programs, adopting energy-efficient appliances and equipment, managing time schedules, and implementing the prepaid metering system. The study suggested that the firm commitments and participation from all parties in universities are needed towards achieving a sustainable campus.
\end{abstract}

Keywords: Sustainable Energy; Energy Conservation; Energy Efficiency; Sustainable Facilities Management

2398-4279 @ 2019 The Authors. Published for AMER ABRA CE-Bs by E-International Publishing House, Ltd., UK. This is an open-access article under the CC BY-NC-ND license (http://creativecommons.org/licenses/by-nc-nd/4.0/). Peer-review under responsibility of AMER (Association of Malaysian Environment-Behaviour Researchers), ABRA (Association of Behavioural Researchers on Asians) and cE-Bs (Centre for Environment-Behaviour Studies), Faculty of Architecture, Planning \& Surveying, Universiti Teknologi MARA, Malaysia.

DOI: https://doi.org/10.21834/ajqol.v4i17.201 


\subsection{Introduction}

The concept of sustainability generally refers to efforts to adopt or optimize environmental, economic, and social dimensions, as well as practices (Hitchcock \& Willard 2006; Petrini \& Pozzebon 2010) and is sometimes referred to as the triple bottom line (Koukiasa 2011). The focus of these dimensions is to decrease the present-day ecological impacts in order to preserve the environment for future generations, to provide positive economic growth, and to promote social capital issues for a better quality of life (Dempsey et al. 2011; Rydin \& Holman 2004). The focus of this research is on the importance of sustainability practices in universities that focus on sustainable energy initiative. The energy conservation practice is potentially driving university progress towards a sustainable campus.

Universities are regarded as one of the vital research settings and can play a fundamental role in achieving sustainability goals (Wright \& Wilton, 2012). The importance of universities concerning sustainable development is reflected in various international agreements such as the Copernicus University Charter for Sustainable Development issued by the International Association of Universities and the Kyoto Declaration on Sustainable Development issued by the UNESCO World Declaration on Higher Education (Sabir, 2008). These agreements promote universities as critical institutions in developing sustainable societies. At present, the discussion on sustainable universities has been carried out in the areas of research, education, and administration, including campus operations (McMillin \& Dyball, 2009). Moreover, numerous universities around the world are taking steps to improve their management practices to achieve sustainability (Bajracharya \& Too, 2009). However, according to Carlson (2006), many universities are only embarked on a minor step to gain the appearance of sustainability or "greenwashing," and they are taking a prolonged approach compared to corporations. Universities are supposed to be on the leading edge, but they are falling behind the curve as sustainability has not been integrated into the higher education thoughtfully.

There are various reasons why universities are prominent concerning sustainability issues. Universities are substantially large systems containing lecture classes, cafes, sports hall, student residences, laundry, library, research facilities, and so forth. Moreover, the university campus issue of energy efficiency has been the main topic discussed due to the increase in building energy usage annually (Jomoah et al., 2013). According to Alshuwaikat and Abubakar (2013), the energy efficiency issue should become the main focus on the university campus because it has high energy consumers, high energy cost, contribute to climate changes, and easily affected by the lack of resource of non-renewable energy. Several issues result in wastage of energy used in the university. Thus, the activities taken place on the campus utilize a lot of energy and resources and create wastes (Amaral, Martins, and Gouveia, 2015). As cited in Amaratunga and Baldry (2000), sustainability practices are essential to universities because they are trying to improve their efficiency while facing the challenge of rising operating costs and increasing user expectations. Overall, energy performance in university buildings is, for the most part, affected by its existing systems and components, especially mechanical systems, building envelope, and lighting systems. For instance, in building especially mechanical components, comprises of heating, ventilation, 
and air-conditioning (HVAC) system known as the most building energy-consuming equipment (Ruparathna et al., 2016). Therefore, in the context of energy conservation, reducing energy consumption is critical to improving campus sustainability (Faghihi, Hessami, \& Ford, 2015). This paper aims to promote the implementation of energy conservation practices in a university where it should be aware of the impacts that their activity had on the environment.

\subsection{Literature Review}

Over the last ten years, there has been increasing awareness globally about environmental sustainability due to the impact of development (Woodruff \& Mankoff 2009). Urgent actions and solutions are required to minimize the detrimental impacts of environmental challenges such as climate change, ozone depletion, pollution, soil degradation, and deforestation (Banerjee 2002; Hansen 2006). Moreover, environmental changes due to global warming, carbon dioxide emissions due to climate change can be seen through the ongoing worldwide have concentrated consideration on the earth (Kim, Jung, Seok, \& Yang, 2015). Environmental sustainability addresses the impact of activities on the environment by minimizing the use of resources, minimizing the production of waste and pollution, protecting biodiversity and the natural environment, and using energy efficiently. Table 1 illustrates the environmental dimension of sustainable development and the areas of concern.

Table1: Areas of concern of the environmental dimension

\begin{tabular}{|c|c|}
\hline Dimension & Environmental \\
\hline 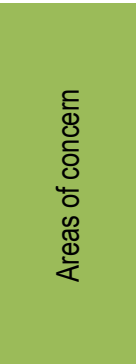 & $\begin{array}{l}\text { - Climate change } \\
\text { - Resources } \\
\text { - Internal environment } \\
\text { - External environment } \\
\text { - Wildlife } \\
\text { - Biodiversity } \\
\text { - Water } \\
\text { - Energy } \\
\text { - Waste } \\
\text { - Materials and components }\end{array}$ \\
\hline
\end{tabular}

Source: Adopted and adapted from Harris 2003; Khalfan 2002; Reffat 2004b

Millions of people in third world nations are affected by environmental degradation, and this may increase the negative impact on human well-being around the world in the next few generations. The research stated that the university campus has excessive emissions and an immense misuse of energy consumption activities. Thus, the world must reduce energy consumption to build a sustainable society (Gyberg and Palm, 2009). Energy conservation is, therefore, one of the prominent solutions for a sustainable energy future.

The term energy conservation has various definitions. As a rule, energy conservation can be portrayed as 'using less of energy service and therefore saving the energy that would be 
expected to provide it (IEA, 2007). Based on Weenen (2000), the term is often defined as "to reduce the consumption of non-renewable resources." In other means by Yen, Syarafina, and Wai (2010), energy is the limit of a physical system to perform work and characterizes energy conservation as activities that reduce end-use demand for energy by reducing the service demanded. According to the Nuclear Supporter Energy (2008), energy conservation covers two aims, which are to improve the efficiency with which energy is used in machines, appliances, buildings, and motor vehicles and to cut out the wasteful use of energy. Banerjee (2015), describe that energy conservation alludes to decreasing energy consumption by utilizing less of an energy service. On a larger scale, energy conservation is a significant component of energy policy and recognized as the most economical solution to energy deficiencies.

Besides, the Supporters of Nuclear Energy (2008) argued that energy conservation as a tool for reducing demand and has to be something more than a brief response to national difficulties. It requires a change of attitude and behavior towards the use of energy. Most of the building occupant's beliefs that it was someone else's problem to conserve the energy (Maistry and Annegarn, 2016). "People will think, 'oh, they will turn off everything so I can just go," in this case, individuals will have other unfortunate habits because they want to depend on other individuals (Emeakaroha, Ang, \& Yan, 2012). It can say that students tended not to make full utilize the chance to energize energy conservation, and this may cause a total of electricity consumption in getting gradually increase. These factors are associated with energy conservation on the university campus. For example, in a study of university organization by Kollmuss and Agyeman (2002) found that more than 46 percent of faculty members did not switch off overhead lights before leaving their office. This negative attitude creates wastage and unnecessary demand for energy. Waste of energy happens whenever a lack of control from buildings and workspaces. The implication when people not concerned about conserving energy, the operating cost will become high, increase negative environmental impact, and low healthy lifestyle.

On the contrary, people who are conserving energy by reducing energy services may increase financial capital, national security, environmental quality, and personal financial security (Noranai and Azman, 2017). Indeed, by improving energy conservation, it can lower overall demand on the system and can thereby lower the wholesale market clearing price for electricity due to less energy needed. A lower clearing price allows lower electric prices for all customers.

The International Energy Agency, energy demand is growing at a faster rate of $36 \%$ between 2008 and 2035. Noranai and Azman (2017), prove that energy consumption has drastically expanded in building over the previous decade because of populace development, additional time spent indoors, expanded interest for building capacities and indoor environmental quality, and global climate change. This is because energy sources are among one the fundamental necessities that have been utilized since the presence of a human on earth. Figure 1 above shows five years of increments total electricity consumption in Malaysia. 


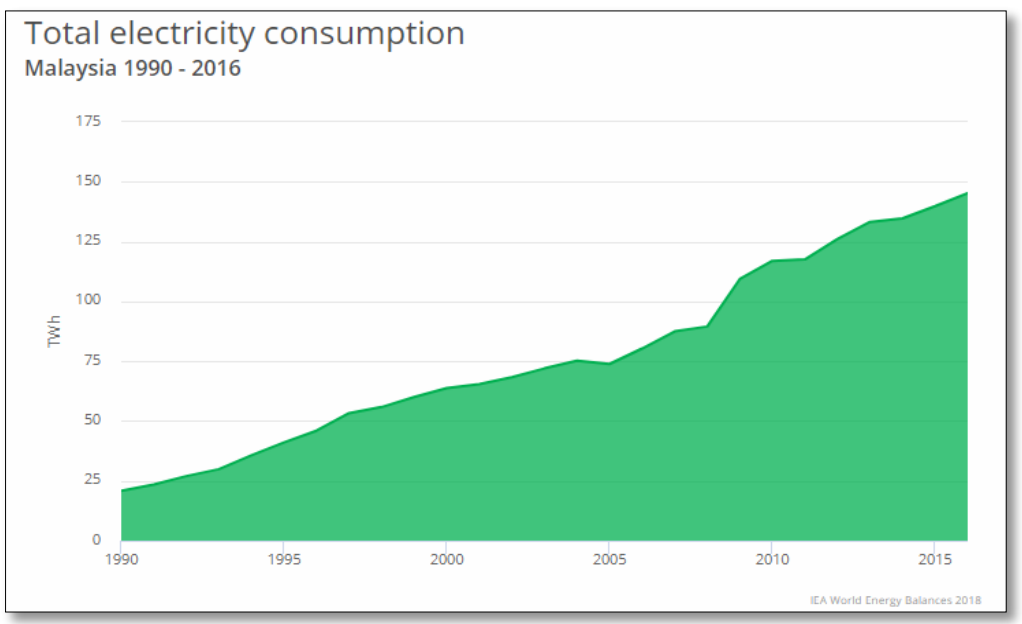

Figure 1: Five years increments of total electricity consumption in Malaysia (Source: IEA World Energy Balance 2018)

Generally, conserving the energy efforts of universities are not new. Energy consumption has become the main target of sustainability efforts due to its relationship to environmental degradation and potential economic savings. Amaral, Martins, \& Gouveia (2015) stated in 2006, the Association for the Advancement of Sustainability in Higher Education (AASHE) was formally propelled in January 2006, serving as the first professional North American universities association for the campus sustainability community. In 2007, a gathering of college and university presidents made an unusual activity to lead the sustainability effort by universities by focusing on the climate change challenge. The American College \& University Presidents Climate Commitment is a high- permeability exertion to address global warming through a joint commitment to accomplish climate neutrality for their campuses and to build up the ability of society to do likewise (Dautremont-Smith et al., 2006).

In general, to reduce the overall energy consumption significantly on campus, appropriate procedures are critical to success (Ting, Mohamed, \& Choong, 2012). For example, according to Hasim et al. (2017), various universities in Australia incorporated sustainable energy initiatives in their management approach (whether they have undertaken, are undertaking or will undertake this in their plan). The initiatives concerned renewable energy and efficiency. For example, for the University of South Australia, numerous energy-efficient projects are featured, such as intelligent energy management systems, power factor correction, and on-demand lighting. These have contributed to a 700,000 kWh saving per year. In Deakin University, some energy efficiency programs have been implemented across campus, together with energy and emissions audits. Eighty-seven percent (34 universities) of Australian universities showed awareness of sustainable energy.

Moreover, energy performance in university buildings is, for the most part, affected by its 
existing systems and components, especially mechanical systems, building envelope, and lighting systems. For mechanical components, mostly comprise of heating, ventilation, and air-conditioning (HVAC) system known as the most building energy-consuming equipment (Ruparathna et al., 2016). While, for the lighting system, the techniques for improvement in lighting system efficiency incorporates the lamp installation with high luminous efficacy, conservation to higher energy execution lighting, task lighting design, integration of daylight and lighting systems and installation of occupancy sensor at workspace (Ruparathna et al., 2016). Soares et al. (2015) pointed out the importance of changing energy-use behaviors, imposing new policy measures, and providing technological development as part of the main required changes to improve energy efficiency. Therefore, universities became aware of the impacts that their activity had on the environment. As such, environmental concerns worked as the very first driving force towards sustainability.

In the Malaysian context, the Malaysia Ministry of Education has urged all education centers to save energy (The Star, September 13, 2007). Administrators in Malaysian universities also are concerned about the expensive monthly electricity bill. Energy costs more than ten million ringgit annually, and this burdens to the universities (Choong et al., 2009). This leads to new thinking and searches for new methods of conserving energy that needs to be studied and used in order to save costs. Table 1 below showed the summary of issues and practice of energy conservation in the university organizations.

Table 1. The summary of issues and practice of energy conservation in the university

\begin{tabular}{|c|c|c|}
\hline No & Literature Review & Finding \\
\hline 1 & $\begin{array}{l}\text { Issues on energy } \\
\text { conservation in university }\end{array}$ & $\begin{array}{l}\text { Lack of information and knowledge } \\
\text { Lack of control over energy consume } \\
\text { Lack of commitment } \\
\text { Lack of enforcement and awareness } \\
\text { Lack of maintenance }\end{array}$ \\
\hline 2 & $\begin{array}{l}\text { Current energy practice in } \\
\text { the university }\end{array}$ & $\begin{array}{l}\text { Green campus program } \\
\text { Behavioral change } \\
\text { Building management and smart system } \\
\text { Green campus initiatives } \\
\text { Course timetabling approaches } \\
\text { Energy management team } \\
\text { Application of meter readings }\end{array}$ \\
\hline 3 & Most effective initiatives & $\begin{array}{l}\text { Public awareness } \\
\text { Energy efficiency in electrical equipment } \\
\text { Energy usage management and monitoring } \\
\text { Prepayment metering system of energy motor }\end{array}$ \\
\hline 4 & $\begin{array}{l}\text { Strategy to improve energy } \\
\text { conservation practice in the } \\
\text { university }\end{array}$ & $\begin{array}{l}\text { Developing a smart campus } \\
\text { Guideline for a new building } \\
\text { Gaining top management commitment } \\
\text { Raising energy awareness } \\
\text { Providing energy education } \\
\text { Developing energy conservation behavior } \\
\text { Changing existing building } \\
\text { Creating energy policy }\end{array}$ \\
\hline
\end{tabular}




\subsection{Methodology}

This study employed semi-structured interviews as they provided a clear set of instructions for interviewers and better qualitative data (Cohen \& Crabtree, 2006) and offered flexibility to different participants while covering the same areas (Noor, 2008). They also provided the ability to clarify new emerging data as well as being highly suitable for confidential subject matter due to the trust and rapport (forming bond) being built between both parties during the process (Dewey \& Zheng, 2013). Therefore, this technique was relevant to this research. The target participants were those who are knowledgeable concerning activities being undertaken and among the person who handles energy management in university. The preference for selecting this position was to ensure that the most appropriate participants in the university's department were interviewed. It was recognized that senior positions are more knowledgeable and would deliver reliable information concerning activities being undertaken, in planning and future developments (Warren-Myers, 2013). Two (2) participants from each university were invited to participate in these interviews to a total of six (6) interviewees. These interviews engaged with different participants in each university to enhance the reliability of the data collected, to avoid bias, and to illustrate the conclusion on the themes that had emerged. Thus, the interviews were useful in generating more credible data. Guest, Bunce, and Johnson (2006) suggested that a range between six and 12 participants for interviews was adequate for developing meaningful themes and achieving research objectives. With the total number of 6 interviewees, this study conformed to this suggestion. Each interview lasted between 35 and 45 minutes and was audio-recorded using a digital recorder with the permission of the participants. Three universities were chosen, which are Universiti Tenaga Nasional, Universiti Kuala Lumpur, and Universiti Teknologi MARA, Shah Alam. Data collection was undertaken from 01 March to 01 May 2019. Table 2 below showed the details of the interviewees.

Table 2. Details of Interviewees

\begin{tabular}{cll}
\hline No & \multicolumn{1}{c}{ Organization } & \multicolumn{1}{c}{ Position } \\
\hline 1 & Facility Management Department & Energy Manager \\
\hline 2 & $\begin{array}{l}\text { Head of Department College of Energy } \\
\text { Economics and Social Sciences }\end{array}$ & Senior Lecturer \\
\hline 3 & Facilities Maintenance Department & Senior Manager \\
\hline 4 & Facilities Maintenance Department & Chargeman \\
\hline 5 & Facilities Maintenance Department & Energy Manager \\
\hline 6 & Facilities Maintenance Department & Electrical Engineer \\
\hline
\end{tabular}

The data from the semi-structured interview were presented accordingly in the tabulation. Results obtained from the literature review and data collection was used as a basis to conclude, and it outlined the suggestion that can be taken to provide understanding in energy conservation practice to the maximum extent possible as well as achieving the aim of the research. Besides, this method would interpret the information correctly without losing any critical keywords. 


\subsection{Results and Discussion}

Table 3 shows the current practice of energy conservation in universities. The study found that seven (7) energy conservation practices were implemented. Where the rank number one was on energy awareness program with the rate by $5 / 6$ numbers of interviewees said the universities create an awareness program to conserve the energy. They are followed by rank number two, which is time scheduling management mentioned by $4 / 6$ of interviewees. Rank number three is using energy-efficient appliances and types of equipment mentioned by $3 / 6$ of interviewees, while for prepaid meter, de-lamping method and audit of equipment fall to rank number four and mention by $2 / 6$ interviewees. Last but not least, $1 / 6$ interviewees said the practice of energy conservation is with the energy management program.

Table 3. The current energy conservation practice in universities

\begin{tabular}{|c|c|c|c|c|c|c|c|c|}
\hline \multirow{2}{*}{ Initiatives } & \multicolumn{2}{|c|}{ Case Study A } & \multicolumn{2}{|c|}{ Case Study B } & \multicolumn{2}{|c|}{ Case Study C } & \multirow{2}{*}{ Total } & \multirow{2}{*}{ Rank } \\
\hline & 1 & 2 & 3 & 4 & 5 & 6 & & \\
\hline $\begin{array}{l}\text { Energy awareness } \\
\text { program }\end{array}$ & $\bullet$ & $\bullet$ & $\bullet$ & & $\bullet$ & $\bullet$ & $5 / 6$ & 1 \\
\hline $\begin{array}{l}\text { Time scheduling } \\
\text { management }\end{array}$ & $\bullet$ & $\bullet$ & $\bullet$ & $\bullet$ & & & $4 / 6$ & 2 \\
\hline $\begin{array}{l}\text { Energy-efficient } \\
\text { appliances and } \\
\text { equipment's }\end{array}$ & $\bullet$ & & $\bullet$ & & $\bullet$ & & $3 / 6$ & 3 \\
\hline $\begin{array}{l}\text { Prepaid metering } \\
\text { system }\end{array}$ & $\bullet$ & $\bullet$ & & & & & $2 / 6$ & 4 \\
\hline De-lamping method & $\bullet$ & & $\bullet$ & & & & $2 / 6$ & 4 \\
\hline Audit of equipment & & & & & $\bullet$ & $\bullet$ & $2 / 6$ & 4 \\
\hline $\begin{array}{l}\text { Energy management } \\
\text { planning }\end{array}$ & $\bullet$ & & & & & & $1 / 6$ & 5 \\
\hline
\end{tabular}

Energy awareness should become a part of university culture and requires more extensive thoughtfulness regarding all the critical components of energy management. The campaign program, the majority of the universities have utilized a current notice board dedicated to energy display as a point of communication. The universities additionally place the screen where everyone can see it, including visitors. A comprehensive energy education campaign that is propelled at the university will mean to change every one of the individuals from the university people group into a new energy-efficient culture. This campaign will keep the network continually educated regarding the advancement that the university is making towards vitality proficiency (Delport, 2000). Moreover, Volyand et al. (2016) suggested that giving people the knowledge and understanding of the issue of energy conservation and consequently enabling them to make an informed decision about the issue, as well as share the information with others. Indeed, energy education is the best approach to build up a legitimate energy education scheme in the field of energy conservation by introducing new courses for both conventional and sustainable energy sources.

Moreover, the second rank for the current practice of energy conservation in university is time scheduling management in terms of the HVAC system, lighting, plug loads, and others. Most of the universities that practiced time scheduling management are using the Building 
Automation System (BAS), especially air-conditioning and lighting. For instance, the facility management will look into supply and demand for air-conditioning because it does consume a very large of energy consumption. The function is to improve the occupant's comfort, proficient operation of building systems, decrease in energy consumption and operating costs, and developed the life cycle of utilities. For example, they stated that:

"Before this, an operation hour for the chiller is 24 hours, a chiller is charging at night and will discharge during the day. Now, the facility management changes a little bit of chiller operation hour, during the day, which is, the chiller will discharge from 08:00 a.m until 5:00 p.m; and from 5:00 p.m to 11:00 p.m, facility management will utilize the energy storage. Therefore, the facility management can save $R M 50,000.00$ per month and total for a year save $R M 600,000.00$ because the operation hours for the chiller is only running 18 hours, which directly reduce the operation running hours".

Furthermore, energy-efficient appliances and equipment help to reduce energy demand and also decrease energy costs for consumers. According to the U.S Department of Energy (2015) stated that appliance and equipment efficiency standards have filled in as one of the country's effective policies for improving energy efficiency and saving consumers energy and money. Available efficiency technologies take into account a massive decrease in energy consumption. These technologies require consumers to perform simple actions, such as replacing office appliances, lighting, and component or systems with increasingly productive models (Mahreen and Patidar, 2015). In pretty much every example, a similar service is provided lighting to the same lumens standard, cooling, or heating to a similar temperature or meeting the equivalent output. Therefore, improved technology allows these activities while using less power. This view was expressed in responses from participants from UNITEN, who said that:

"We have started to change our appliances and equipment to energy-efficient, but our campus is huge, so we are trying to change the energy-efficient appliances and equipment stage by stage."

Besides, the U.S. perspective, the Department of Energy's (DOE's) Appliance and Equipment Standards Program (Standards Program) covers over 60 products, representing about $90 \%$ of home energy use, $60 \%$ of commercial building energy use, and approximately $30 \%$ of industrial energy use. Standards implemented since 1987 saved American consumers $\$ 58$ billion on their utility bills in 2014 and have helped the United States avoid emissions of 2.3 billion tons of carbon dioxide $\mathrm{CO}$, which is proportionate to the yearly $\mathrm{CO} 2$ emissions from nearly 500 million vehicles.

Also, facility management in UNITEN has introduced prepaid meter for students who stay in hostels. The consumption of electricity in a hostel is high ranges from RM100 to RM150 monthly consists of four people in one unit apartment. For example, as revealed by one participant:

"We, as a private university, should balance the operating cost and revenue cost. Of course, people will say private university wants to make a profit, but at least we can cover the cost of revenue, so what we do is to charge students on the use of electricity in a hostel which as our concept is paying as you use."

According to Farrow, Gilles, \& Mzoughi, (2018), in the course of the most recent couple 
of years, prepayment meters either in electricity, water or piped gas, have been proposed as an innovative solution aimed at facilitating affordability and decreasing the expense of utilities. This component necessitates that users pay for the delivery of goods or services before their consumption. Along these lines, users hold credit and, after that, use the service until the credit is depleted. Globally, prepayment systems have been introduced for the first time in South Africa but currently widely used in the UK, Turkey, and India (Tewari and Shah, 2003).

Besides, de-lamping is another effective method to consider during an upgrade process in existing facilities. Delamping technique is an excellent methodology to decrease energy consumption and still hold legitimate light levels (Zhou et al., 2013). It consists of removing unnecessary lamps or fixtures in areas with higher than needed illumination. Moving the lower wattage is an extraordinary thought when the light levels are higher than required, and the ballast accommodates multiple wattages. Many private sectors and public sector building managers engage in delamping to achieve energy conservation. Based on Hong et al., ( 2016), this energy management technique is so well established and effective at reducing peak power use. For example, a participant from UNITEN stated that:

"We are also doing an energy audit on the de-lamping method, what we do is, we relocate back the lighting in a building, for example, every corner of my room, the brightness of the lamp is dim compared to the lamp on my writing desk."

Many private sectors and public sector building managers engage in de-lamping to achieve energy conservation. Moreover, there is a small trial on reducing the monthly energy bill of boys and ladies hostels by referring to the energy audit of equipment. The management hostel will seize the equipment's that conserve a lot of electricity and goods that are not safe to use. Therefore, there is an excellent possibility of energy conservation by replacing existing equipment with energy-efficient devices. According to Soares et al. (2015), an energy audit is a very first step to improve the energy efficiency of any building and was directed dependent on the investigation of the energy utilization profiles and bills. Krarti (2000) suggested that four types of energy audits commonly applied, such as 'Walk-Through Audit,' 'Utility Cost Analysis,' 'Standard Energy Audit' and 'Detailed Energy Audit.'

Last but not least, Energy Management Systems (EnMS) can assist an organization in establishing sustainable processes to improve energy performance. Energy management incorporates the planning and operation of energy production and energy consumption units. The goals are resource conservation, climate protection and cost savings. It is associated closely to environmental management, production management, logistics and other established business functions. Therefore, strategic planning for a comprehensive energy management plan is essential to conserve energy and energy efficiency.

Next, the study found the most effective initiatives implemented in universities, and Table 4 portrays ranked of the initiatives. Generally, establishing an energy awareness program and focusing on energy-efficient appliances and equipment falls ranked number one. Followed by time scheduling management practice at rank number two and rank number three go to introducing prepaid metering system and energy management plan. Indeed, In brief, the researcher can see that each university has its management and energy policy. 
Therefore, for the university to embark on improving their sustainable energy practice, they need to invest in educating users.

Table 4. Most effective initiatives energy conservation practice in universities

\begin{tabular}{|c|c|c|c|c|c|c|c|c|}
\hline \multirow{2}{*}{ Initiatives } & \multicolumn{2}{|c|}{ Case Study A } & \multicolumn{2}{|c|}{ Case Study B } & \multicolumn{2}{|c|}{ Case Study C } & \multirow{2}{*}{ Total } & \multirow{2}{*}{ Rank } \\
\hline & 1 & 2 & 3 & 4 & 5 & 6 & & \\
\hline $\begin{array}{l}\text { Energy awareness } \\
\text { program }\end{array}$ & - & $\bullet$ & $\bullet$ & $\bullet$ & $\bullet$ & $\bullet$ & $6 / 6$ & 1 \\
\hline $\begin{array}{l}\text { Energy-efficient } \\
\text { appliances and } \\
\text { equipment's }\end{array}$ & - & - & - & - & - & $\bullet$ & $6 / 6$ & 1 \\
\hline $\begin{array}{l}\text { Time scheduling } \\
\text { management }\end{array}$ & - & $\bullet$ & - & • & & & $4 / 6$ & 2 \\
\hline $\begin{array}{l}\text { Prepaid metering } \\
\text { system }\end{array}$ & - & - & & & & & $2 / 6$ & 3 \\
\hline $\begin{array}{l}\text { Energy management } \\
\text { planning }\end{array}$ & - & $\bullet$ & & & & & $2 / 6$ & 3 \\
\hline
\end{tabular}

The following Table 5 shows propose strategies for energy conservation in universities. This strategy, hopefully, will improve the implementation of sustainable energy in universities.

Table 5 Propose strategies by interviewees

Objective

\begin{tabular}{|c|c|}
\hline \multirow{6}{*}{$\begin{array}{l}\text { To improve energy } \\
\text { conservation in } \\
\text { university }\end{array}$} & Impus \\
\hline & Research, Development, Demonstration and Dissemination (R,D,D\&D) \\
\hline & Legislative and Regulatory Support \\
\hline & Outreach Program \\
\hline & Green Procurement Standard \\
\hline & Existing Building Desian \\
\hline
\end{tabular}

Firstly, one of the strategies that the university has developed is a Smart UniverCity. The objective of the Smart UniverCity is to make the university's campus an innovation platform and hub for ideas to create a more sustainable future. For instance, the university can plan on creating a micro smart-grid that will likewise enable the university to generate its electricity using solar panels and biomass.

The second strategy is Research, Development, Demonstration, and Dissemination $(R$, $D, D \& D$ ), funding of research is needed in tertiary institutions and appropriate research institutes to create building designs that take into account a longer period of use of passive energy than obtained presently. Additionally, building users investing in energy efficiency will regularly recover costs in a short period through lower energy costs. In developing countries, high consumption in new buildings will increase the demand for new supply and grid limits. Therefore, the facility management needs to discuss with the architect, designer, and contractor on what are the requirements needs for a new building.

The third strategy for legislative and regulatory support will involve the institutionalization of standards and codes, as well as incentives and motivation that will enhance the promotion 
of energy conservation. For the buildings sector, various professionals and all other stakeholders should be engaged with the legislative and regulatory processes for necessary and functional legal measures and regulatory practices.

Forth strategy is an outreach awareness program that key elements of a successful energy management plan that can help identify cost-saving opportunities in places that might not have considered. This awareness program can help the university in lower operating and production costs, improve competitive organization position, can reduce GHG emissions, increase operational efficiency, create a better work environment for lectures and staffs, assemble an energy management team, build a strategic framework for energy management and make organization a leader in energy efficiency.

Fifth, the strategy of Green Procurement means purchasing products and services that cause minimal unfriendly environmental impacts. It incorporates human health and environmental concerns into the search for high-quality products and services at competitive prices. According to interviewee from UiTM Shah Alam point out:

"Besides that, we should use green procurement, which is compulsory. All things have to do with planning, for example, change the lights to LED lights stage by stage and change the chiller that keeps the energy-efficient or more efficient product."

Last but not least, existing building design should aim at minimizing heat gain indoors and maximizing evaporative cooling, with the goal that users of these spaces can have satisfactory thermal comfort and consequently make less demand for active energy. Therefore, the investigation of climate data closely related to the design environment will lead to more adequate and precise design decisions in terms of spatial organization, appropriate orientation, prevention of heat gain into spaces, and a better choice of building materials.

\subsection{Conclusion}

In a nutshell, seven practices of energy conservation in university runs well in each university selected. From seven identified initiatives, five effective practices are contributing to the most efficient practices, which are providing energy awareness program, using energy-efficient appliances and equipment, managing activities and academic time scheduling, using the prepaid metering system, and also involved in energy management planning. In addition, the strategies suggested by interviewees consists of developing the smart campus, R, D, D\&D, legislative and regulatory support, outreach program, green procurement standard, and existing building design. In the face of increasing demand for energy and especially electricity in all sectors, more efficient use of energy has to be considered as one of the major options to achieve sustainable development in university. Therefore, this study suggests three approaches to university campuses to promote the implementation of energy conservation practice in university.

The first approach requires all facilities management teams and top management to understand and play their roles in promoting and increasing awareness of energy conservation among students and staff in the university. The senior management's commitment is always a higher priority in ensuring the triumphs of the whole program. 
Without responsibility from management on financial, time, personnel, and any other relevant resources, the program will not accomplish the desired results. Secondly, the energy management teams should provide a firm energy policy for setting goals and integrating energy management planning in university.

\section{Acknowledgment}

The authors gratefully acknowledge the support grant in producing this paper under the Geran Penyelidikan LESTARI (Project Code: 600-IRMI/MyRA 5/3/LESTARI (056/2017) funded by Universiti Teknologi MARA, Malaysia.

\section{References}

A. Kollmuss, J. Agyeman (2002). Mind the gap: why do people act environmentally and what are the barriers to proenvironmental behavior. Environmental Education Research, 8 (2002), pp. 239-260

A.R. Carrico, M. Reimer (2011). Motivating energy conservation in the workplace: An evaluation of the use of grouplevel feedback and peer education. Journal of Environmental Psychology, 31 (2011), pp. 1-13

Amaral, L., Martins, N., \& Gouveia, J. (2015). Quest for a sustainable university: a review. Emerald insight: International Journal of Sustainability in Higher Education, 155-177.

Amaratunga, D., \& Baldry, D. (2000). Assessment of facilities management performance in higher education properties. Facilities, 18(7/8), 293-301.

Bajracharya, B., \& Too, L. (2009). Building a sustainable campus: A case study of Bond University. Paper presented at the State of Australian Cities national conference, Perth, WA, Australia.

Carlson, S. (2006, October). In search of the sustainable campus. The Chronicle of Higher Education, 53(9), $10-14$.

Cohen, D., \& Crabtree, B. (2006). Qualitative research guidelines project. Robert Wood Jonhson Foundation.

Creswell, J. W. (2009). Mapping the field of mixed methods research. Journal of Mixed Methods Research, 3(2), 95108.

Deakin University. (2010). Retrieved 01 August 2010, 2010, from http://deakin.edu.au/

Delport, G. (2000). Africampus - Energy Management on Campus. Centre for New Electricity Studies. Department of Electrical and Electronic Engineering , 1-6.

Dewey, S., \& Zheng, T. (2013). Ethical Research in a Fraught Environment Ethical Research with Sex Workers (pp. 39-55): Springer.

Emeakaroha, A., Siang, C., \& Yan, Y. (2012). Challenges in Improving Energy Efficiency in a University Campus Through the Application of Persuasive Technology and Smart Sensors. Energy, 1-29. Pp. 290-318.

Faghihi, V., Hessami, A., \& Ford, D. (2015). Sustainable campus improvement program design using energy efficiency and conservation. Journal of Cleaner Production, 107, 400-409. 
Farrow, K., Gilles, G., \& Mzoughi, N. (2018). Less is more in energy conservation and efficiency messaging. Energy Policy, 1-6.

Guest, G., Bunce, A., \& Johnson, L. (2006). How Many Interviews are Enough? An Experiment with Data Saturation and Variability. Field methods, 18(1).

Gyberg, P. and Palm, J. (2009), "Influencing households' energy behavior - how is this done and on what premises?", Energy Policy, Vol. 37 No. 7, pp. 2807-2813.

Hong, T., Taylor-Lange, S. C., Simona, Yan, D., \& Corgnati, S. P. (2016). Advances in research and applications of energy-related occupant. Energy and Buildings behavior in buildings , 694-702.

Ibrahim M Jomoah, Sreerama Kumar R. (2013) Ethernet TCP/IP based building energy management system in a university campus in Saudi Arabia, International Journal Of Energy And Environment, Volume 4, Issue 6, 2013 pp.1033-1040.

International Energy Agency (IEA). 2007. CO2 Emissions from Fossil Fuel Combustion. http://www.iea.org/Textbase/publications/free_new_Desc.asp?PUBS_ID=1825

Kim, D. W., Jung, J. W., Soek, H. T., \& Yang, J. H. (2012). Survey and Analysis of Energy Consumption in University Campuses. International Sustainable Building Asia, 1-6.

L.P. Amaral, N. Martins, J.B. Gouveia (2015). Quest for a sustainable university: a review. Int. J. Sustain. High. Educ., 16 (2015), pp. 155-172, 10.1108//JSHE-02-2013-0017

M S Hasim, A E Hashim, N R M Ariff, Z Sapeciay, A S Abdullah (2018). Commitment to sustainability: A content analysis of a website for university organizations. IOP IOP Conference Series: Earth and Environmental Science. 117012046

Maistry, N., Annegarn, H., \& Annegarn, H. (2016). Using energy profiles to identify university energy reduction opportunities. Emerald insight: International Journal of Sustainability in Higher Education, 188-211. http://doi.org/10.1108//JSHE-09-2014-0129

Mahreen, G. S., \& Patidar, S. (2015). Understanding the energy consumption and occupancy of a multi-purpose academic building. Energy and Buildings , 155-165.

McMillin, J., \& Dyball, R. (2009). Developing a Whole-of-University Approach to Educating for Sustainability: Linking Curriculum, Research, and Sustainable Operations. Journal of Education for Sustainable Development, 3(1), 55-64. doi: $10.1177 / 097340820900300113$

N. Soares and P. Conceição, Pereira da Silva, P.; Dias Pereira, L, Ferreira, J. (2015) "Energy efficiency of higher education buildings : a case study," International Journal of Higher Education., vol. 16, no. 5, pp. 669-691, 2015.

Noor, K. B. M. (2008). Case study: a strategic research methodology. American Journal of Applied Sciences, 5(11), 1602-1604.

Noranai, Z., \& Azman, A. (2017). Potential reduction of energy consumption in the public university library. IOP Conference Series: Materials Science and Engineering (pp. 1-7). Johor: IOP Publishing Ltd.

R. Ruparathna, K. Hewage, R. Sadiq (2016). Improving the energy efficiency of the existing building stock: a critical review of commercial and institutional buildings

Renew Sustain Energy Rev, 53 (2016), pp. 1032-1045, 10.1016/j.rser.2015.09.084

Sabir, M. (2008). The role of universities in sustainable development with special focus on Pakistan. Universiti 76 
Malaysia Perlis (UNIMAP) Digital library Journal, 60-68.

Soares, N., Pereira, L. D., Ferreira, J., Conceicao, P., \& Pereira, P. (2015). Energy efficiency of higher education buildings : A case study. International Journal of Sustainability in Higher Education , 669-691.

Ting, L. S., Mohamed, A. H., \& Choong, W. W. (2012). Proposed implementation strategies for energy sustainability on a Malaysian university campus. Emerald insight: Business Strategy Series, 209-218.

Van Weenen, H. 2000. Towards a vision of a sustainable university. International Journal of Sustainability in Higher Education Vol. 1, Issue 1, pp. 20 - 34.

Warren-Myers, G. (2013). Sustainable management of real estate: is it really sustainability? Journal of sustainable real estate, 4(1), 177-197.

Wright, T. S. A., \& Wilton, H. (2012). Facilities management directors' conceptualizations of sustainability in higher education. Journal of Cleaner Production, 31, 118-125. doi: 10.1016/j.jclepro.2012.02.030

Yen, Ng Sock, E. S. Abdul Shakur, and Choong Weng Wai (2010). "Energy conservation opportunities in Malaysian universities." Malaysian Journal of Real Estate 5.1 (2010): 26-35.

Zhou, X., Yan, J., Zhu, J., \& Cai, P. (2013). Survey of energy consumption and energy conservation measures for colleges and universities in Guangdong province. Energy and Buildings , 112-118. 